of the reign of Hung $\mathrm{Wu}$, an emperor of the Ming dynasty (A.D. 1392), two "Comforters" were appointed to the state of $\mathrm{Pa}$-pai-hsi-fu-kuo, namely, one to Che-na and the other to Ta-tien. In the 5th year of the reign of Yung Lo, an emperor of the same dynasty (A.D. 1408), the state remained neutral. A military contingent was demanded from it, and it sent tribute to China.

It is further stated, in Kang-chien-ho-p'ien, Y Yü-p'i-litai-t'ung-chien, and Kang-chien-i-chih-lu, that in the 3rd regnal year of Emperor Yung Lo (A.D. 1406) a Chinese general named $\mathrm{Mu} \mathrm{Ch}^{\prime} e n g$ demanded the submission of Pa-pai-ta-tien, which is also called Pa-paihsi-fu-kuo. During the early days of the Ming dynasty (A.D. 1368-1644) two "Comforters" were appointed to that state. It is mentioned in the Yünnan T'ung Chih, or Gazetteer of Yünnan, that in A.D. 1408 a Hsin-fu or metal plaque was granted by the Emperor to the "Comforter" of Pa-pai-ta-tien, or Timāsa.

Taw Sein Ko.

\title{
Further Letter from Mr. Cochrane
}

Your letter of the 28th instant gives the information I required.

There may have been a mistake in the date of the Nan-chao plaque. I am not a Chinese scholar, and had to rely entirely on the date given by Professor Parker. If such documents are customarily dated from the exact year of issue, a mistake is presumable.

That Chieng-Mai was at least nominally under the Chinese during the Mongol-Chinese dynasty there is no sufficient reason to doubt, and that state may still have recognized such overlordship at the beginning of the fifteenth century, though the Shan records here say nothing about it. That the Chinese had at least nominal control of the sub-kingdom on the Cambodia at that time there can be no doubt whatever. If the so-called 
"province of Chieng-Mai" extended eastward to the Cambodia at that date, identifying Timāsa with ChiengMai would have been quite natural, though the Cambodia River region in particular may have been meant. Line fences were often set over, and set back again or torn down altogether, according to the power and ambition of the various squabbling Shan princes.

I did not intend to identify the Nan-chao plaque, or the one given to the nephews, with the one found in Assam ; I meant merely to say that I regarded it as one of the same kind, i.e. as a "letters patent" and not as a "god". This you show clearly to have been the case from your history of the word somdeo, from the Chinese sum-lok, corrupted in Shan into sum-loo, and further corrupted by the Āhoms into som-deo. Several words spelt here with an $l$ are spelt with a $d$ in Āhom (as dao for liao, a sword). The deo is not, therefore, to be confounded with the Sanskrit deva. In the Āhom and Kham-ti Shan writings of Assam a "god" is uniformly represented by the word $h p i$ (or pi, according to taste in transcription), as it is here. If the "Comforters" were always indigenous chiefs (and Shans, over this way), it helps to account for the frisky intermeddling of Shans in Burman affairs during the Mongol-Chinese dynasty. It also helps to explain the meaning of Mr. Parker's statement that they were "withdrawn" in 1342 .

The statement (JRAS., p. 287, April, 1913) is itself a Chinese puzzle. What is meant by "The Āhoms invaded Assam in A.D. 1228", that they "kept up communication with their Shan relations in Chieng-Mai after they had settled in Assam", and that they "obtained the metal plaque from them"? At that time the generalin-chief (Hsö-ka-pha) of the Mao Shan king (Hsö-hkanhpa) conquered Assam, and the same king had already conquered Chieng-Mai. He held both under tribute till he died, after a long and eventful reign. This seems to 
be as certain as anything in the Shan records. If communication was kept up, it was, in the first instance, through the Mao (or Pawng) kingdom of what is now Eastern Burma. Hsö-hkan-hpa was followed on the Mao throne by weaklings. That Chieng-Mai between 1270 and 1408 may have retaliated and conquered the Northern Shans, including the Mao apanage (the Āhoms of Assam), is possible, but the Shan records here make no mention of such a pleasant social visit.

The Ảhoms were menaced by the Muslim conquest of Northern India, and had several armed conflicts with the Muslims, but during that period they seem never to have received any aid from China; if they received such aid they were ungrateful, for they make no mention of it in their records. Still, I am inclined to think that the relation between the Chinese and all of the Shans from Chieng-Mai to the valley of the Brahmaputra was much closer than the latter acknowledge or than has ever been conceded. While practically independent of China, there still seems to have been a certain recognition of Chinese suzerainty. That Chinese "letters patent" was not fooling-round up there in Assam for nothing.

I happen to know a scholarly missionary (the Rev. W. Clifton Dodd, D.D.) of the American Presbyterian Mission of Northern Siam, working among the Laos. I may do well to write to him to see what light he may be able and willing to give on the whole matter. I hear that he, or one of his associates, has collected a large number of historical manuscripts.

W. W. Cochrane.

The MEANING OF THE WORDS 'ALì ḨUBBIHI IN QUR. II, 172

In the well-known verse (172) of the second chapter of the Qur'an which enumerates the elements of piety

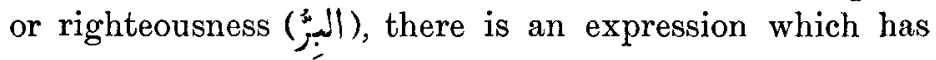

